\title{
Found in translation: the global constitution of the modern international order
}

\author{
Jaakko Heiskanen (D) \\ Department of Politics and International Studies, University of Cambridge, UK \\ Corresponding author. E-mail: jwh48@cam.ac.uk
}

(Received 3 June 2019; revised 29 April 2020; accepted 1 June 2020; first published online 15 July 2020)

\begin{abstract}
This paper brings the notion of translation into dialogue with the growing literature on international hierarchies and the historical origins of the modern international order. Leveraging on the writings of Karl Marx, I draw parallels between the exchange of commodities and the translation of linguistic signs in order to unmask the inequalities and asymmetries that pervade the practice of translation. I then deploy these theoretical insights to illuminate the global constitution of the modern international order. In this Marx-inspired reading, the modern international order is cast as the 'universal equivalent' that has crystallized out of the asymmetries and contradictions that pervaded the global political economy of conceptual exchange in the long $19^{\text {th }}$ century. As universal equivalent, the modern international order effectively functions as the socially recognized 'metalanguage' that undergirds the miracle of global translatability and makes international/ interlingual relations possible on a global scale. The paper concludes by considering the implications of the analysis for the future of international/interlingual hierarchies and world order.
\end{abstract}

Keywords: concepts; Eurocentrism; hierarchy; international order; language; translation

We only ever speak one language. We never speak only one language. - Jacques Derrida (1998)

It is often said that something - meaning, significance - is lost in translation. What the reiteration of this truism overlooks is that, by the same token, something is also found in translation. At the very least, what is found in translation is a certain violence towards linguistic and cultural difference. ${ }^{1}$ Accordingly, a central claim of this paper is that the lens of translation offers fruitful avenues into the study of social, cultural, and linguistic hierarchies in international relations: what is found in translation is, in the first place, asymmetry and inequality. But this is not all. By recasting

\footnotetext{
${ }^{1}$ Venuti 1996.

(c) The Author(s), 2020. Published by Cambridge University Press. This is an Open Access article, distributed under the terms of the Creative Commons Attribution licence (http://creativecommons.org/licenses/by/4.0/), which permits unrestricted re-use, distribution, and reproduction in any medium, provided the original work is properly cited.
} 
translation as an omnipresent feature of communication, I further demonstrate that every social order is constituted through translation. The violence that is found in translation is thus, quite literally, a foundational violence. Consequently, if the modern international order is understood as a concrete social formation rather than an abstract theoretical category, as a product of history rather than a transcendental given, then what is found in translation is nothing less than the global constitution of the modern international order - the modern international order is found(ed) in translation.

Following the 'linguistic turn' of the 1980s, the field of International Relations (IR) has witnessed a burgeoning of interest in the study of language, discourse, rhetoric, and other cognate notions. ${ }^{2}$ More recently, there has been a growing interest in the analysis of concepts: some have traced the historical development of specific concepts such as 'empire', 'friendship', ${ }^{4}$ and 'foreign policy', ${ }^{5}$ while others have explored more general questions about how concepts structure the theory and practice of international politics. ${ }^{6}$ As Stefano Guzzini observes, theorization of concepts is key to understanding the ontology of the modern international order: our concepts constitute the 'unfinished dictionary' of the international. ${ }^{7}$ And yet, amidst this flourishing literature on language and concepts, the problem of translation is hardly mentioned. In what language is our 'unfinished dictionary' written? One of the few scholars to break IR's silence on translation is Einar Wigen, who has sought to reframe international relations as 'interlingual relations'. ${ }^{8}$ Some valuable research also exists on how individual concepts such as 'democracy" and 'security' ${ }^{10}$ are translated. Much more work is needed, however, to fully appreciate the role of translation in international/interlingual relations.

A core aim of this paper is to bring the notion of translation to bear on the growing literature on international hierarchies - a literature which, depending on the author, either nuances or directly challenges the 'Westphalian' interpretation of the modern international order as a 'flat' or 'anarchical' plane of formally equal sovereign states. ${ }^{11}$ Specifically, this paper adopts what Ayşe Zarakol has labelled the 'broad' interpretation of international hierarchy: in contrast to the 'narrow' interpretation, where hierarchical relations appear as mere surface phenomena in an otherwise anarchical field, the 'broad' interpretation of hierarchy emphasizes how the concept of anarchy is itself hierarchical insofar as it obscures the existence of important social inequalities between states. ${ }^{12}$ In challenging some of the basic theoretical presuppositions of the discipline, the 'broad' interpretation of hierarchy also resonates with postcolonial approaches that emphasize the profound

\footnotetext{
${ }^{2}$ See, for example, Der Derian and Shapiro 1989, Hansen 2006, Krebs and Jackson 2007.

${ }^{3}$ Jordheim and Neumann 2011.

${ }^{4}$ Roshchin 2017.

${ }^{5}$ Leira 2019.

${ }^{6}$ Berenskoetter 2017, Jordheim and Wigen 2018.

${ }^{7}$ Guzzini 2013, 534-37.

${ }^{8}$ Wigen 2015, Wigen 2018.

${ }^{9}$ Schaffer 1998.

${ }^{10}$ Stritzel 2014.

${ }^{11}$ See, for example, Lake 2009, Hobson 2014, Zarakol 2017a.

${ }^{12}$ Bially Mattern and Zarakol 2016, Zarakol $2017 \mathrm{~b}$.
} 
Eurocentrism of IR's conceptual apparatus. ${ }^{13}$ These critical approaches can, I argue, be furthered by paying attention to the dissemination and translation of concepts through space and time. In the words of Margrit Pernau, 'conceptual history offers a way to at once incorporate power and materiality into the analysis of language, take regional differences in the actors' interpretation of their experiences seriously, and thus provide a tool for provincializing European analytical concepts. ${ }^{14}$ But instead of limiting itself to the history of a single concept, this paper tackles a much larger topic: the global political economy of conceptual exchange through which the modern international order was forged.

The paper is divided into four sections and a conclusion. The first two sections are concerned with the basic theoretical building blocks of the argument: concepts and their translation. Taking its cue from Reinhart Koselleck, the first section demonstrates that concepts are not mere words but miniature theories of the social world: by structuring experiences and expectations, concepts constitute social imaginaries that allow actors to navigate the world around them. Unfortunately, Koselleck's approach remains decidedly monolingual and he explicitly denies the possibility of a 'metalanguage' that could mediate across linguistic divides. Accordingly, the purpose of the second section is to challenge Koselleck's methodological nationalism and to lay the theoretical groundwork for international/interlingual conceptual history. It does so by challenging the traditional distinction between intralingual and interlingual translation and recasting translation as an omnipresent feature of social interaction. Seen in this light, the very possibility of communication implies the existence of some kind of socially recognized 'metalanguage'.

The third section of the paper contains the brunt of the theoretical argument. Drawing parallels between the exchange of commodities and the translation of linguistic signs, I argue that the emergence of a socially recognized metalanguage is analogous to the emergence of a 'universal equivalent' as described by Karl Marx. In addition to illuminating the social processes of exchange that give rise to a metalanguage, this Marx-inspired account also foregrounds the asymmetries and inequalities that pervade the practice of translation. The fourth section then mobilizes these theoretical insights to read the formation of the modern international order through a translation perspective. By outlining the unequal pattern of conceptual exchange in the long $19^{\text {th }}$ century, I demonstrate the asymmetrical yet complementary role of the West and the rest in the constitution of the modern international order: overwhelmingly, it was non-Western languages that were restructured to mirror Western conceptual structures, rather than the reverse. In particular, I show how this asymmetrical series of exchanges culminates in the institutionalization of the Western experience of modernity in the conceptual architecture of the modern international order, which begins to function as universal equivalent - in effect, the basic concepts of the modern international order provide the socially recognized metalanguage that allow international/interlingual relations

\footnotetext{
${ }^{13}$ See, for example, Kayaoğlu 2010, Seth 2011, Hobson 2012.

${ }^{14}$ Pernau 2016, 484.
} 
to take place on a global scale. The paper concludes by considering the implications of the analysis for the future of international/interlingual hierarchy and world order.

\section{Theorizing concepts}

The study of concepts has been dominated by two approaches that emerged concurrently yet independently. One is the so-called Cambridge School approach to the history of political thought, associated with the likes of Quentin Skinner and J. G. A. Pocock; the other is the Begriffsgeschichte tradition pioneered by Reinhart Koselleck. ${ }^{15}$ In this section, I begin by briefly discussing the Cambridge School approach to conceptual history (or rather, the lack thereof) before detailing a more nuanced theory based on the work of Koselleck.

The Cambridge School is known for its historicist and contextualist mode of interpretation. Inspired by speech-act theory, Skinner has styled his approach to conceptual history as the study of 'rhetorical redescription'. ${ }^{16}$ 'The understanding of texts', Skinner writes, 'presupposes the grasp of what they were intended to mean, and how this meaning was intended to be taken'. ${ }^{17}$ The aim of the scholar should be 'to recover this complex intention on the part of the author. ${ }^{18}$ A crucial corollary of this contextualist stance is that the Cambridge School leaves no room for the diachronic analysis of concepts: 'there can be no histories of concepts as such; there can only be histories of their uses in argument'. ${ }^{19}$ The most that any scholar can do is to offer snapshots of particular historical contexts in which particular words were used by particular authors. 'My almost paradoxical contention', Skinner concludes, 'is that the various transformations we can hope to chart will not strictly speaking be changes in concepts at all. They will be transformations in the applications of the terms by which our concepts are expressed'. ${ }^{20}$ In the same vein, Pocock maintains that a conceptual history can never amount to anything more than a history of the usage of words: 'a history of the concept of, for example, "the state" will in fact be a history of the various ways in which the words status, Staat, état, estate, stato, and so forth have been used'. ${ }^{21}$

Koselleck's Begriffsgeschichte does not directly contradict the Cambridge School approach, but instead offers a supplementary twist that avoids reducing concepts to mere words. Addressing Skinner and Pocock's claims regarding the impossibility of conceptual history, Koselleck offers a brilliant riposte:

Every reading by later generations of past conceptualizations alters the spectrum of possible transmitted meanings. The original contexts of concepts change; so, too, do the original or subsequent meanings carried by concepts. The history of concepts may be reconstructed through studying the reception,

\footnotetext{
${ }^{15}$ For an overview and comparison, see Palonen 1999.

${ }^{16}$ Skinner 1999, 67.

${ }^{17}$ Skinner 1969, 48.

${ }^{18}$ Skinner 1969, 49.

${ }^{19}$ Skinner 1988, 283.

${ }^{20}$ Skinner 2002, 179.

${ }^{21}$ Pocock 1996, 53.
} 
or, more radically, the translation of concepts first used in the past but then pressed into service by later generations. Therefore, the historical uniqueness of speech acts, which might appear to make any history of concepts impossible, in fact creates the necessity to recycle past conceptualizations. The record of how their uses were subsequently maintained, altered, or transformed may properly be called the history of concepts. ${ }^{22}$

In this passage, Koselleck makes the same critical move against the Cambridge School as Jacques Derrida has made against the speech-act theory of John Searle: the meaning of a speech-act may be determined by its context, but this context is boundless. ${ }^{23}$ Any context is open to further description and any description of a context can in turn be grafted onto that context, creating a new context. As a result, the intended meaning of a word or text is always haunted by alternative meanings that cannot be reduced to or derived from the intentions of the author. Koselleck characterizes this haunting as 'the contemporaneity of the noncontemporaneous' (die Gleichzeitigkeit des Ungleichzeitigen). ${ }^{24}$

It is precisely the excess of meaning, the contemporaneity of the noncontemporaneous, that differentiates a concept from a word. 'A concept may be attached to a word', Koselleck explains, 'but it is simultaneously more than that word'. ${ }^{25} \mathrm{~A}$ word 'becomes elevated to the status of a concept' when it 'combines in itself an abundance of meanings, ${ }^{26}$ This is comparable to Gilles Deleuze and Félix Guattari's understanding of a concept as a 'multiplicity' formed of a finite number of components: 'The concept is a whole because it totalizes its components, but it is a fragmentary whole'. ${ }^{27}$ The concept of the state, for example, knits together a myriad of elements such as territoriality, sovereignty, citizenship, legislation, taxation, and military force. A concept that occupies a central position in a semantic cluster Koselleck calls a 'basic concept' (Grundbegriff). Basic concepts are 'an inescapable, irreplaceable part of the political and social vocabulary'. ${ }^{28}$ Because they are located at the epicentre of a cluster, basic concepts are also the most ambiguous concepts of all: 'they are pivots around which all arguments turn'. ${ }^{29}$

The fundamental aim of conceptual history is to investigate how concepts are used 'to order experience'. ${ }^{30}$ By abstracting and generalizing about the infinite complexity of the world, concepts help actors make sense of the world around them. ${ }^{31} \mathrm{~A}$ concept, therefore, is like a miniature theory of the social world: 'It bundles together the richness of historical experience and the sum of theoretical and practical lessons drawn from it', as Koselleck puts it. ${ }^{32}$ In this way, a concept encapsulates both a

\footnotetext{
${ }^{22}$ Koselleck 1996, 62-63, emphasis added.

${ }^{23}$ Derrida 1988.

${ }^{24}$ Koselleck 2011, 18.

${ }^{25}$ Koselleck 2011, 19.

${ }^{26}$ Koselleck 2011, 20.

${ }^{27}$ Deleuze and Guattari 1994, 15-16.

${ }^{28}$ Koselleck 1996, 64.

${ }^{29}$ Koselleck 1996, 65.

${ }^{30}$ Koselleck 2011, 21.

${ }^{31}$ Berenskoetter 2017, 154-55, Palonen 1999, 42.

${ }^{32}$ Koselleck 2011, 20.
} 
'space of experience' constituted of past events and a 'horizon of expectation' that opens up towards the future. ${ }^{33}$ It is precisely due to this inherent historicity that a concept can never be given a final definition, only a contestable interpretation. ${ }^{34}$

By structuring the experiences and expectations, concepts function as the constitutive elements of social imaginaries: 'concepts create, through their "topography", the reality to which we relate and attribute significance'. ${ }^{35}$ Charles Taylor defines a social imaginary as 'the ways in which people imagine their social existence, how they fit together with others, how things go on between them and their fellows, the expectations that are normally met, and the deeper normative notions and images that underlie these expectations'. ${ }^{36}$ In anthropological terms, a social imaginary may be understood as a 'cognitive schema' or 'cultural model' that is embodied in institutions, practices, and material objects. ${ }^{37}$ Indeed, the material world is a key factor in determining the experiences and expectations of actors. ${ }^{38}$ 'Put metaphorically', Koselleck once mused, 'concepts are like joints linking language and the extra-linguistic world'. ${ }^{39}$

\section{Translating concepts}

Koselleck believed that a concept was always tied to a particular language and, consequently, that a 'metalanguage' would be necessary for conceptual history to be able to transcend linguistic borders. His conclusion, however, was unwavering: 'there is no such metalanguage'. ${ }^{40}$ In this way, Koselleck firmly closed the door to international/interlingual conceptual history and yielded to methodological nationalism. ${ }^{41}$ The purpose of this section is to challenge Koselleck's overly pessimistic conclusion not just by mobilizing insights from other scholars, but also, more importantly, by demonstrating that possibilities for international/interlingual conceptual history can be found within the interstices of Koselleck's own writings. By foregrounding some of Koselleck's passing remarks on translation, I demonstrate that translation is in fact not opposed to, but an integral feature of, conceptual history.

Roman Jakobson helpfully distinguishes three kinds of translation: intralingual translation or rewording; interlingual translation or translation proper; and intersemiotic translation or transmutation whereby signs are translated into a nonverbal system of symbols. The term 'translation' is traditionally reserved for interlingual translation, as reflected in Jakobson's description of this as 'translation proper'. ${ }^{42}$ This privileging of interlingual translation and its categorical separation from intralingual translation implies that languages exist as coherent and bounded systems. In

\footnotetext{
${ }^{33}$ Koselleck 2004, 255-75.

${ }^{34}$ Koselleck 2011, 20.

${ }^{35}$ Freeden 1996, 57.

${ }^{36}$ Taylor 2002, 106.

${ }^{37}$ Strauss 2006, 331.

${ }^{38}$ Pernau 2016, 487.

${ }^{39}$ Koselleck 1996, 61.

${ }^{40}$ Koselleck 2002, 217. See also Koselleck 2006, 111.

${ }^{41}$ On methodological nationalism and conceptual history, see Marjanen 2009, Marjanen 2017.

${ }^{42}$ Jakobson 2000, 114.
} 
the wake of the poststructuralist turn, however, such a position is no longer tenable: 'There is impurity in every language. ${ }^{43}$ Instead of seeing translation as the transfer of meaning between closed linguistic systems, it is necessary to recognize that languages themselves are accomplishments of translation that is continually taking place between dialects, sociolects, and idiolects. In the words of Kari Palonen, 'translation does not refer to exceptional situations, but, on the contrary, forms an omnipresent procedure of interpretation'. ${ }^{44}$ Even between two individuals speaking the same language, there is always an 'existential distance' that prevents spontaneous understanding and makes translation necessary. ${ }^{45}$ Seen in this light, translation becomes a pragmatic hermeneutic solution to the problem of understanding, accomplishing what Hans-Georg Gadamer calls a 'fusion of horizons' between actors or texts. ${ }^{46}$ The difference between interlingual and intralingual translation is therefore one of degree rather than kind. The translation of a foreign language text 'is simply an extreme case of hermeneutical difficulty'. ${ }^{47}$

Insofar as the transfer of meaning from one context to another entails a translation, conceptual history and translation go hand-in-hand. Indeed, a close reading of Koselleck's writings reveals that the notion of translation is far from absent in his work. In his aforementioned response to Skinner and Pocock, for example, Koselleck refers to 'the translation of concepts first used in the past but then pressed into service by later generations'. ${ }^{48} \mathrm{~A}$ few pages later in the same paper, he writes that the task of the conceptual historian is 'to ask what strands of meaning persist, are translatable and can again be applied; what threads of meaning are discarded; and what new strands are added'. ${ }^{49}$ 'Any translation into one's own present implies a conceptual history', he concludes elsewhere. ${ }^{50}$ In these passages, Koselleck is, of course, using the word 'translation' to refer to the transfer of meaning from one context to another through time. Yet, this is not essentially different from the transfer of meaning from one language to another or from one geographical location to another - the past is a foreign country, as they say. Ultimately, what matters is the spatiotemporal distance between two or more contexts: 'we can refer to all translations as the inter-contextual transfer of concepts, irrespective of whether or not the sources and scholar share a common language. ${ }^{51}$

What makes interlingual translation especially difficult is that no two languages are identical. In addition to possessing different sets of words, different languages have different grammatical and syntactical patterns and therefore require different information to construct sentences. Jakobson gives the following example:

In order to translate accurately the English sentence 'I hired a worker', a Russian needs supplementary information, whether his action was completed

\footnotetext{
${ }^{43}$ Derrida $1985,100$.

${ }^{44}$ Palonen 2003b, 17. See also Steiner 1975, 47.

${ }^{45}$ Palonen 2003b, 16.

${ }^{46}$ Gadamer 2004, 305.

${ }^{47}$ Gadamer 2004, 389.

${ }^{48}$ Koselleck 1996, 62, emphasis added.

${ }^{49}$ Koselleck 1996, 68, emphasis added.

${ }^{50}$ Koselleck 2002, 21, emphasis added.

${ }^{51}$ Palonen 2012, 80-81.
} 
or not and whether the worker was a man or a woman, because he must make his choice between a verb of completive or noncompletive aspect - нанял or нанимал - and between a masculine and feminine noun - работника or работницу. ${ }^{52}$

Due to these structural discrepancies between English and Russian, if the same isolated sentence were to be translated back and forth between the two languages, it would quickly lose the meaning of its initial content - akin to the loss of value in a circular series of unfavourable currency transactions. ${ }^{53}$ Wigen offers a similar economic metaphor, referring to the loss of meaning in translation as 'semantic transaction costs'. ${ }^{54}$ Given that meaning is context-bound, semantic transaction costs can be minimized through a careful consideration of the context of the original text: 'the richer the context of a message, the smaller the loss of information'. ${ }^{55}$ However, the infinitude of any context also means that semantic transaction costs can never be completely eliminated: translation, whether intralingual or interlingual, inevitably entails transformation. ${ }^{56}$ Conceptual exchange is always-already-also conceptual change.

Translation, then, is not just a necessary and omnipresent feature of communication; it is also, as Derrida puts it, 'another name for the impossible'. ${ }^{57}$ This paradox of necessity and impossibility stems from the nature of concepts themselves, as elaborated in the previous section. On the one hand, by linking words together in semantic clusters, concepts form uneven topographies that structure the flow of signifiers; basic concepts emerge as nodes around which signifiers begin to circulate, making it possible to fix meanings to words. On the other hand, precisely because concepts are clusters of relations-in-process that can never be fixed once and for all, they also preclude a one-to-one correspondence between a word and a concept - as Koselleck emphasizes, a concept always contains an excess of meaning that renders it something more than a word. In this way, the very nature of concepts rules out two extreme scenarios, both of which would make translation pointless: the total freeplay of words, where no meaning could be fixed, and the one-to-one correspondence of word and concept, where all linguistic differences would evaporate.

If translation is both necessary and impossible, then so, too, is a metalanguage. On the one hand, Koselleck is certainly correct to assert that a metalanguage is, strictly speaking, an impossibility - the diversity of human languages ensures this. On the other hand, it is equally indisputable that translation is constantly taking place both within and across linguistic boundaries, not least within the walls of international organizations. ${ }^{58}$ This suggests that some kind of metalanguage can be brought into being through social practice. But how, exactly, does such a socially recognized metalanguage emerge? How does the impossible become possible? To

\footnotetext{
${ }^{52}$ Jakobson 2000, 116.

${ }^{53}$ Jakobson 2000, 116.

${ }^{54}$ Wigen 2015, 429-30.

${ }^{55}$ Jakobson 2000, 116.

${ }^{56}$ Derrida 1981, 20.

${ }^{57}$ Derrida 1998, 57.

${ }^{58} \mathrm{Pym} 2004$.
} 
answer these questions, the next section turns to the political economy of conceptual (ex)change.

\section{The political economy of conceptual (ex)change}

The necessity and impossibility of translation means that some kind of socially recognized metalanguage is also both necessary and impossible. To illuminate how such a metalanguage may emerge through social practice, this section builds parallels between the exchange of commodities and the translation of linguistic signs. Specifically, I draw on Marx's theory of value to explain how the contradictions of the exchange process impel the emergence of 'a socially recognized (gültige) universal equivalent, which seems to homogenize everything, or to reduce everything to a common denominator'. ${ }^{59}$ By enabling the equation of non-equivalents, the universal equivalent effectively functions as a metalanguage that mediates across linguistic differences.

\section{The commodity and the sign}

To begin with, consider the basic structure of the commodity and the linguistic sign. Marx identifies two components of the commodity: use-value and exchangevalue. Use-value is 'conditioned by the physical properties of the commodity, and has no existence apart from the latter' ${ }^{60}$ Exchange-value, in contrast, 'appears first of all as the quantitative relation, the proportion, in which use-values of one kind exchange for use-values of another kind'. ${ }^{61}$ Exchange-value is therefore not an inherent property of the commodity, but a product of relations between commodities. As Marx emphasizes, 'the commodity never has this form [exchange-value] when looked at in isolation, but only when it is in a value-relation or an exchange relation with a second commodity of a different kind'. ${ }^{6}$

Use-values, for Marx, are 'the material bearers' of abstract exchange-values. ${ }^{63}$ This distinction between use-value as the qualitative or material dimension of the commodity and exchange-value as its quantitative or abstract dimension is analogous to Ferdinand de Saussure's splitting of the linguistic sign into two components: the signifier (word or sound-image) and the signified (concept). The signifier, similar to use-value, is the 'sensory' or 'material' quality of the sign, whereas the signified, similar to exchange-value, is 'more abstract'. ${ }^{64}$ Signifiers serve as the material bearers of signifieds. Moreover, in the same way that the exchange-value of a commodity is only conceivable in relation to other commodities, the valuation of words is only possible through the arrangement of signs in relation to one another: 'the meaning of any linguistic sign is its translation into some further, alternative sign'. ${ }^{65}$ The meaning-value of a word is therefore not an inherent or natural

\footnotetext{
${ }^{59}$ Shell 1982, 107.

${ }^{60}$ Marx 1976, 126.

${ }^{61}$ Marx 1976, 126.

${ }^{62}$ Marx 1976, 152.

${ }^{63}$ Marx 1976, 126.

${ }^{64}$ de Saussure 1959, 66.

${ }^{65}$ Jakobson 2000, 114.
} 
property of that word, but emerges historically out of the semantic relations within which it is embedded. ${ }^{66}$

\section{The asymmetry of exchange}

In commodity exchange, the simple form of value is given by the equation ' $x$ commodity A is worth $y$ commodity B'. For example, '20 yards of linen are worth 1 coat'. Marx's crucial insight was to demonstrate that the two commodities in the equation play different roles, which he calls the 'relative form' and the 'equivalent form' ${ }^{67}$ In the given example, it is the linen that has the relative form whereas the coat has the equivalent form. Instead of expressing its own value, the coat serves as the material through which the exchange-value of the linen is expressed - in effect, the use-value of the coat transforms into the exchange-value of the linen. ${ }^{68}$ The equation is, of course, reversible: if 20 yards of linen are worth one coat, then one coat is worth 20 yards of linen. But regardless of which way around the equation is written, one commodity will take the relative form whereas the other takes the equivalent form. Whenever a commodity takes the relative form, this 'presupposes that some other commodity confronts it in the equivalent form'. ${ }^{69}$

Translation, likewise, presupposes the existence of two texts that play asymmetrical roles: a source text and a translated text. ${ }^{70}$ The source text corresponds to Marx's relative form, whereas the translated text corresponds to the equivalent form. Through the establishment of equivalential links between the two texts, the words of the translated text are made to mirror the concepts inscribed in the source text. In this way, the translated text effectively becomes a material bearer of the meaning-value inscribed in the original source text: the words that compose the translated text are not supposed to express their own meaning-value, but serve instead as the concrete substance through which the concepts of the source text are expressed. The equivalence between the two texts is, of course, 'artificial, fictive, something that has to be produced on the level of translation itself. But it must be produced'. 71

\section{The emergence of the universal equivalent}

When considered in a broader multilateral economy of exchange, the simple form of value outlined above is unsatisfactory. Each commodity is implicated in an infinite number of relationships wherein it may take either the relative or the equivalent form of value: it is a motley mosaic of disparate and unconnected expressions of value'. ${ }^{72}$ The concrete solution to the tension between use-value and exchangevalue, which plagues each commodity, is provided by a 'universal equivalent' against which the exchange-value of all commodities can be measured. To be

\footnotetext{
${ }^{66}$ de Saussure 1959, 71-78.

${ }^{67}$ Marx 1976, 139.

${ }^{68}$ Marx 1976, 148.

${ }^{69}$ Marx 1976, 140.

${ }^{70}$ Pym 2010, 38-45.

${ }^{71}$ Pym 2010, 50.

${ }^{72}$ Marx 1976, 156.
} 
clear, the universal equivalent does not magically abolish the underlying contradictions between use-value and exchange-value. Instead, by serving as the external manifestation of the exchange-value of all commodities, it provides these contradictions with 'the form within which they have room to move'. ${ }^{73}$

The development of the universal equivalent proceeds through two phases, which Marx calls the 'general form' and the 'money form' ${ }^{74}$ The initial emergence of the universal equivalent under the general form is the upshot of foreign communities coming into contact with one another. 'Exchange', Marx explains, 'begins not between the individuals within a community, but rather at the point where the communities end - at their boundary, at the point of contact between different communities. ${ }^{75}$ This claim is supported by anthropological evidence, which shows that the practice of barter - the exchange of one commodity for another usually takes place between strangers or enemies rather than friends. ${ }^{76}$ In situations of frequent commercial interaction between foreign communities, a universal equivalent organically arises out of the exchange process when a particular commodity 'is no longer exceptionally, but habitually, exchanged for various other commodities.' ${ }^{77}$ For example, 'when a person exchanges his linen for many other commodities, and thus expresses its value in a series of other commodities, it necessarily follows that the other owners of commodities exchange them for the linen, and therefore express the values of their various commodities in one and the same third commodity, the linen'. ${ }^{78}$ In this way, the linen spontaneously accumulates the functions of universal equivalent, becoming exchangeable for a multiplicity of other commodities. Under the general form, the universal equivalent tends to be a widely-available and especially useful or desirable commodity that attracts a large number of simultaneous requests of exchange - historical examples include salt, cattle, furs, corn, and slaves. ${ }^{79}$ Given their spontaneous character and lack of institutionalization, the universal equivalents that appear under the general form retain an ephemeral quality: 'The universal equivalent form comes and goes with the momentary social contacts which call it into existence. It is transiently attached to this or that commodity in alternation' ${ }^{80}$

With the intensification and institutionalization of exchange, the universal equivalent 'crystallizes out into the money-form'. ${ }^{81}$ If under the general form the universal equivalent tends to be a commodity with significant use-value, the intensification of exchange and the fixing of the universal equivalent in the form of money entail the opposite: 'that commodity which has the least utility as an object of consumption or instrument of production will best serve the needs of exchange as such ${ }^{82}$ The institutionalization of the money form is therefore not a

\footnotetext{
${ }^{73}$ Marx 1976, 198.

${ }^{74}$ Marx 1976, 157-63.

${ }^{75}$ Marx 1973, 882. See also Lapavitsas 2005, 105-08.

${ }^{76}$ Graeber 2011, 28-34.

${ }^{77}$ Marx 1976, 158.

${ }^{78}$ Marx 1976, 157.

${ }^{79}$ Marx 1973, 165-66, Marx 1976, 183, Lapavitsas 2005, 107, Žižek 2008, 26.

${ }^{80}$ Marx 1976, 183.

${ }^{81}$ Marx 1976, 183.

${ }^{82}$ Marx 1973, 166.
} 
purely organic upshot of exchange, but a social accomplishment that generally requires some degree of centralization under a political authority. ${ }^{83}$ Historically, precious metals such as gold and silver have been especially well suited to play the role of the money commodity due to their durability, homogeneity, divisibility, and portability. ${ }^{84}$ Today, in testimony to the centralization of political authority in the hands of the state, the functions of money are chiefly performed by national currencies such as dollars or pounds. However, it is important to emphasize that money itself is nothing more and nothing less than a social form with social functions; this form may be filled and its functions performed by different objects, but these money-objects are not the same thing as money. ${ }^{85}$ 'Gold and silver, in and of themselves, are not money', Marx writes. 'Nature does not produce money, any more than it produces a rate of exchange or a banker. ${ }^{86}$

In the linguistic sphere, the nature of the universal equivalent may be broached through Saussure's distinction between speech (parole) and language (langue). Speech refers to concrete instances of language in use, whether written or spoken, and is thus specific to a particular actor and context. In contrast, language refers to an overarching signifying system regulated by shared rules and conventions. ${ }^{87}$ By providing the general social form in which communication takes place, language effectively serves as the universal equivalent against which the meaning-value of a sign can be measured. Furthermore, given that the meaning-value of a sign emerges from its relationship to other signs, it follows that language-as-such is nothing but a system of differences: 'in language there are only differences without positive terms' ${ }^{88}$ Akin to the abstract form of money-as-such, language-as-such is nothing more and nothing less than a social form with social functions. Neither money nor language has, in and of itself, a positive existence.

In the same way that the functions of money-as-such are performed by particular money-objects, the functions of language-as-such are performed by particular languages. Paralleling the organic emergence of universal equivalents in the economic sphere, localized lingua francas spontaneously and incessantly arise to meet communication needs when foreign linguistic communities come into contact with each other; such lingua francas 'are creatures of time and circumstance and may flourish while they serve a certain purpose'. ${ }^{89}$ The ebb and flow of these organic lingua francas may be contrasted with the standardization of a language through political authority. The institutionalization of the money form in the economic sphere thus finds a parallel in the institutionalization of 'official languages' 90 or 'languages-of-power' ${ }^{\text {'91 }}$ such as King's English or High German. Within a given domain, an official language effectively functions as a universal equivalent that

\footnotetext{
${ }^{83}$ Marx 1976, 180-81.

${ }^{84}$ Marx 1976, 183-84.

${ }^{85}$ Williams 2000.

${ }^{86}$ Marx 1973, 239.

${ }^{87}$ de Saussure 1959, 7-17.

${ }^{88}$ de Saussure 1959, 120. See also Virno 2009.

${ }^{89}$ Ostler 2010, 51.

${ }^{90}$ Bourdieu 1991, 43-65.

${ }^{91}$ Anderson 2006, 45.
} 
mediates across dialects, sociolects, and idiolects. If money monopolizes the ability to buy, ${ }^{92}$ then language monopolizes the conceptual frameworks upon which social imaginaries are founded - there is an intimate connection between structures of power and ways of knowing the world. ${ }^{93}$

\section{The functions of the universal equivalent}

The universal equivalent serves a number of social functions that are 'derived in strict order'. ${ }^{94}$ The first and most fundamental is to serve as the measure value this, indeed, is the essence of the universal equivalent. It is the function of money as measure of value that alleviates the tension between use-value and exchange-value by giving the latter an independent form: 'The need to give an external expression to this opposition for the purposes of commercial intercourse produces the drive towards an independent form of value which finds neither rest nor peace until an independent form has been achieved by the differentiation of commodities into commodities and money' ${ }^{95}$ Because the measure of value is 'a purely ideal act', something that takes place in the mind rather than in the physical world, money appears here 'only in an imaginary or ideal capacity'. ${ }^{96}$ In contrast, the second function of the universal equivalent is to serve as the medium of circulation. This is a 'purely symbolic' function where money appears not in an imaginary capacity, but as some kind of token, such as a metal coin or piece of paper, which serves as 'a symbol of value'. ${ }^{97}$ It is these symbols or tokens of money that are exchanged between buyers and sellers of commodities.

In the linguistic sphere, likewise, language functions as both measure of value and medium of circulation. As measure of value, language exists in a purely imaginary or ideal capacity - the tangible or sensory character of language is irrelevant here. Language as measure of value is therefore not a specific tongue such as English or French, but a shared conceptual framework or social imaginary that accomplishes what Gadamer calls a 'fusion of horizons' between actors or texts. ${ }^{98}$ André Lefevere and Susan Bassnett characterize these conceptual frameworks as the 'textual grids' upon which words or signifiers are embedded: 'these "textual grids" seem to exist in cultures on a level that is deeper, or higher, or whatever metaphor you prefer, than that of language. In other words, the "textual grid" preexists language(s)'.$^{99}$ In the same way that multiple money-objects may function as measure of value in the economic sphere, the same textual grid may be shared by multiple concrete languages: just as money-as-such is not reducible to the particular money-objects that serve as its symbolic representatives, so language-as-such is a metalanguage that is not reducible to any concrete language. A concrete language

\footnotetext{
${ }^{92}$ Lapavitsas 2005.

${ }^{93}$ On the relationship between power and knowledge, see especially Foucault 1984 .

${ }^{94}$ Lapavitsas 1991, 294.

${ }^{95}$ Marx 1976, 181.

${ }^{96}$ Marx 1976, 190.

${ }^{97}$ Marx 1976, 225.

${ }^{98}$ Gadamer 2004, 305.

${ }^{99}$ Lefevere and Bassnett 1998, 5.
} 
such as English or French is instead the medium of circulation, the set of material symbols that carry concepts from sender to receiver.

In sum, the universal equivalent has two basic socioeconomic functions: the first and most fundamental is to serve as the measure of value, the second is to serve as the medium of circulation. These two basic functions - the first imaginary or ideal, the second symbolic or material - reflect the dual structure of the commodity and the linguistic sign from which they stem: in the same way that the commodity is split between abstract exchange-value and concrete use-value, the linguistic sign is split between the abstract signified and the concrete signifier. The dual structure of the commodity and the sign thus not only impels the emergence of a universal equivalent out of the exchange process, but also inscribes an inescapable duality into its form and function. ${ }^{100}$ In the next section, I draw on these theoretical insights to illuminate the historical constitution of the modern international order.

\section{The making of the modern international order}

Equivalence is not a natural relation between systems but constructed through 'active interrelations' ${ }^{101}$ By the same token, the practice of international/interlingual relations on a global scale must be conceived of as a 'historical event' rather than a natural state of affairs. ${ }^{102}$ Specifically, the practice of international/interlingual relations on a global scale depends on a universal equivalent or metalanguage capable of mediating across linguistic differences. The purpose of this section is to demonstrate how the basic concepts of the modern international order have historically come to constitute this global political metalanguage: it is the conceptual architecture of the modern international order that underpins the miracle of global translatability and makes international/interlingual relations possible on a global scale.

Building on the work of Lydia Liu, this section locates the historical origins of the modern international order in the intensification of global conceptual exchange during the long $19^{\text {th }}$ century. ${ }^{103}$ Given how masterfully Liu leverages Marx's theory of value to unveil the structural inequalities that characterize translation, it is

\footnotetext{
${ }^{100}$ Although a detailed examination of the issue is beyond the scope of this paper, it is worth noting that Marx (1976, 227-44) also outlines a third function of money as money, which is itself a composite of three more specific functions: means of hoarding, means of payment, and world money. Following the Lacanian framing of Goux (1990, 47-53), this third function of money may be characterized as its 'real' function, as distinguished from its 'imaginary' (measure of value) and 'symbolic' (medium of circulation) functions. The significance of money's real function lies in the introduction of a temporal gap between the sale and purchase of a commodity, as a result of which money may be hoarded by individuals: the fact that an individual is in possession of money indicates that they are owed commodities. In this way, the temporal gap between sale and purchase provides the structural conditions for the emergence of the credit system alongside the monetary system (de Brunhoff 1976; Lapavitsas 1991). In the linguistic sphere, an analogy can be found in Benveniste's (1971, 43-48) supplementation of the signifier and the signified with the referent: the real function of language pertains to its referential relationship to social reality. Just as the real function of money is centred on a temporal gap between sale and purchase, so the real function of language is centred on a temporal gap between social history and conceptual history (Koselleck 2002, 20-37).

${ }^{101}$ Pym 2010, 47.

${ }^{102}$ Liu 1999, 15.

${ }^{103}$ Liu 1995, Liu 1999, Liu 2004.
} 
somewhat surprising that she does not consider the central role of the universal equivalent in any detail. ${ }^{104}$ This omission is perhaps explained by the fact that Liu's empirical focus is on the bilateral encounter between the English and Chinese languages and, as elaborated in the previous section, the functions of the universal equivalent only really come to the fore when exchanges are taking place between more than two parties. In a bilateral framework, the role of the universal equivalent is quite easy to overlook.

As detailed in the previous section, the emergence of a universal equivalent can be understood in terms of two phases. In the first phase, an especially desirable commodity or text receives numerous simultaneous demands of exchange and becomes exchangeable for a multiplicity of other commodities or texts. In this way, the privileged commodity or text organically accumulates the functions of universal equivalent. Whereas the first phase entails the exchange process spontaneously throwing up localized universal equivalents, the second phase entails the institutionalization of a universal equivalent through some form of political authority - in Marx's terms, this is the passage from the general form to the money form. At this moment, a subtle yet critical shift takes place: once institutionalized, the universal equivalent no longer needs to possess any intrinsic value and may be replaced by any socially recognized symbol. This point is neatly summarized by Slavoj Žižek: 'first, the commodity which serves as "general equivalent" is the one which is most often exchanged, which has the greatest use-value (furs, corn, and so on); then, the relationship is inverted and the role of the "general equivalent" is taken over by a commodity with no use-value (or at least with negligible usevalue) - money (the "money form"). ${ }^{105}$

The historical constitution of the modern international order may be understood in terms of two phases that correspond to Marx's distinction between the general form and the money form. In the first phase, technological innovations and European imperialism propelled the intensification of global exchange and knit the disparate parts of the world into a global system for the first time. Although the beginnings of this process may be traced to the European exploratory voyages of the $15^{\text {th }}$ century, it really culminates in the long $19^{\text {th }}$ century with the consolidation of the nation-state in Europe and the onset of the industrial revolution: it was at this juncture that the 'proto-globalization' of the early modern period gave way to 'modern globalization' and the integration of global exchange on an unprecedented scale. ${ }^{106}$ In this phase, which corresponds to Marx's general form, the Western experience of modernity acquired a privileged status and Western political concepts were widely translated into other languages across the globe. As a corollary to the material superiority of the European colonial powers, the Western experience of modernity effectively began to function as the universal

\footnotetext{
${ }^{104}$ The only discussion of the universal equivalent that I have found in Liu's work is on p. 22 of her essay 'The Question of Meaning-Value in the Political Economy of the Sign', where she mentions the role of gold in Marx's theory of value. The following statement appears bracketed at the end of a paragraph: 'the English language of the late twentieth century would be the closest analogue to the gold of the preceding era' (Liu $1999,22)$. Immediately thereafter, however, Liu's discussion returns to the inequalities characteristic of bilateral linguistic exchanges.

${ }^{105}$ Žižek 2008, 26.

${ }^{106}$ Hopkins 2002. See also Bayly 2004, Osterhammel 2014, Buzan and Lawson 2015.
} 
equivalent relative to which other 'translated' experiences of modernity were measured. Then, in the second phase, which unfolds in the $20^{\text {th }}$ century and corresponds to Marx's money form, the Western experience of modernity becomes institutionalized in the conceptual architecture of the modern international order. As a result of its institutionalization, the universal equivalent is no longer tied to the material superiority of the West and acquires a semi-autonomous status that obscures its Eurocentric constitution.

\section{Universalization}

The first phase of the narrative - conceptual universalization - captures the formative period of the modern international order when peripheral languages were brought in line with Western conceptual structures. This distinction between a Western core and a non-Western periphery is composed of two intertwined layers and requires some unpacking. The first layer concerns the rather contentious distinction between the West and the non-West. ${ }^{107}$ As understood herein, the West is a dynamic sociolinguistic cluster rather than a static geographical category. The notion of the West therefore does not refer to a homogenous territorial bloc, but to a 'denser network of individuals engaged in translation and conversation'. ${ }^{108}$ Understood this way, the West basically functions as a shorthand for the major Western languages. 'The reason IR is able to treat inter-lingual relations between major Western languages as if they involved no semantic transaction cost (moving between different languages as if they were discourses in a single language) is because their languages have become entangled', Wigen explains. ${ }^{109}$ It goes without saying that there are important differences between languages such as English and German, yet their long history of close interaction and shared Greco-Roman heritage means that they 'make use of the same textual grid, with slight variations in emphasis'. ${ }^{10}$ The shared textual grid that undergirds the Western political languages provides a kind of conceptual lingua franca' that facilitates exchanges between them. ${ }^{111}$ Discrepancies in textual grids are usually much greater when translating between a Western and a non-Western language than they are when translating a text within the West. ${ }^{112}$

The second layer is the more abstract distinction between a core and a periphery, which emerges as a systemic effect of the asymmetries that structure the political economy of conceptual exchange. Simply put, 'translations flow more from the core to the periphery than the other way around. ${ }^{113}$ In the overwhelming majority of conceptual transactions that took place in the long $19^{\text {th }}$ century, it was the languages of the European colonial powers that served as source texts while non-Western languages were reduced to the status of equivalents. Through the hegemony of the British Empire in the $19^{\text {th }}$ century and of the United States in the $20^{\text {th }}$, the English language has come to occupy a hyper-central role in this

\footnotetext{
${ }^{107}$ For a critical discussion of the distinction between the West and the non-West, see Hutchings 2011.

${ }^{108}$ Wigen 2018, 7.

${ }^{109}$ Wigen 2015, 430.

${ }^{110}$ Lefevere and Bassnett 1998, 5.

${ }^{111}$ Palonen 2003a, 570.

${ }^{112}$ Lefevere 1999, 76-77.

${ }^{113}$ Heilbron 1999, 435. See also De Swaan 2001.
} 
cultural world-system: circa 1980 , over $40 \%$ of all translated books worldwide were translated from English. Also in a central position are French, German, and Russian, each with a share of approximately $10-12 \%$ in the global translation market. ${ }^{114}$ Crucially, the longstanding mutual entanglement of these colonial ruling languages has the effect of dragging the whole of the entangled Western language group into a privileged position. The notion of the Western core thus becomes legible as a retrospective effect of the concrete historical processes that forged the modern world.

Recognizing the notion of the Western core as an emergent effect of concrete historical processes points to two important caveats. First, the West is not a preexisting or pure origin but a hybridized product of innumerable encounters, exchanges, and entanglements. In the medieval period, for instance, concepts flowed more from the Arabic-speaking world into European languages than the reverse, with Europe having only a peripheral role in a broader Eurasian system of exchange. ${ }^{115}$ Later, too, the emergence of new political concepts such as 'sovereignty' and 'state of nature' in early modern Europe was heavily influenced by ongoing colonial encounters. ${ }^{116}$ The second important caveat is that there exist smaller linguistic communities that are located within the West geographically, but that fall outside the sociolinguistic notion of the Western core due to their marginal status. The Finnish language, for example, did not become entangled with the major Western languages until the mid-19 ${ }^{\text {th }}$ century, when political concepts such as 'state' (valtio), 'society' (yhteiskunta), and 'citizen' (kansalainen) were imported from languages such as Swedish and German. ${ }^{117}$ Understanding the West as a heterogeneous sociolinguistic cluster rather than an undifferentiated territorial entity makes it possible to recognize the existence of these kinds of 'internal peripheries' within the European space without sacrificing the distinction between the Western core and the non-Western periphery, which emerges as a systemic effect of global exchanges.

Following Stefan Nygård and Johan Strang, the universalization of Western political concepts can be theorized from two opposite yet complementary directions: the universalization of the particular and the particularization of the universal. ${ }^{118}$ The first approach emphasizes how the repeated translation of a concept leads to the effacement of its particular historical origins. As described by Christopher Hill, the result of this universalizing process is 'the use of a concept as if it were valid in all places at all times'. ${ }^{119}$ Concepts such as 'civilization' and 'sovereignty', for example, were used not only to buttress the imperial projects of European powers, but also, later, those of the United States and Japan: 'The universalization of these concepts legitimated the organization of the globe as a system of sovereign states and colonial dependencies, strengthening the position of any empire in it'. ${ }^{20}$ In contrast, the second approach to conceptual transfer focuses on the

\footnotetext{
${ }^{114}$ Heilbron 1999, 433-34.

${ }^{115}$ Abu-Lughod 1989, Hobson 2004.

${ }^{116}$ See, for example, Jahn 2000, Anghie 2005, Branch 2012.

${ }^{117}$ Hyvärinen et al. 2003, Stenius 2004.

${ }^{118}$ Nygård and Strang 2017, 61-65.

${ }^{119}$ Hill 2013, 135.

${ }^{120}$ Hill 2013, 149.
} 
particularizing role of the peripheries: actors located in peripheral communities tend to be more aware of the fact that they are borrowing and translating concepts, and, as a result, they are more likely than their counterparts at the core to recognize the existence of many rival universalisms. ${ }^{121}$ This has been demonstrated, for example, in the reception of new political concepts in the Nordic countries - a region that was 'close to, but not quite part of, the core'. ${ }^{122}$ Seen in this light, peripheral communities are by no means mere passive receivers of concepts emanating from the core, but active participants in their universalization. Liu eloquently describes this as the 'coauthoring' of global linguistic commensurability, where 'both the dominator and the dominated participate in the making of this miracle of universal communication but determine the outcome of such exchanges differently.' ${ }^{123}$

Paying attention to the asymmetrical process of conceptual universalization helps to foreground relationships of space, time, and power. A 'universal mindset' is much more likely to prevail at 'cultural centers' than peripheries: 'Ultimately, it is about power-relations and hierarchies that determine who can afford to ignore whom'. ${ }^{124}$ In the long $19^{\text {th }}$ century and beyond, the material superiority of the West has ensured that the direction of travel of political concepts has been principally from the West to the non-West. A key factor here is the political and economic pressure that Western countries have been able to place on non-Western ones, but another, equally significant, is that 'Western languages produce and deploy desired knowledge more readily than Third World languages do'. ${ }^{125}$ An important consequence of this asymmetrical political economy of conceptual (ex) change has been the restructuring of many non-Western languages: 'because the languages of Third World societies [...] are "weaker" in relation to Western languages (and today, especially to English), they are more likely to submit to forcible transformation in the translation process than the other way around. ${ }^{126}$ For example, Talal Asad tells us that 'from the nineteenth century, Arabic as a language has begun as a result to undergo transformation (lexical, grammatical, semantic) that is far more radical than anything to be identified in European languages - a transformation that has pushed it to approximate to the latter more closely than in the past.'. ${ }^{127}$

To illustrate the restructuring of non-Western languages, consider the case of China. To begin with, it is important to recall that concepts are not mere words, but the building-blocks of social imaginaries that underpin political practices. Prior to its encounter with the European imperial powers, China had seen itself as the 'Middle Kingdom' (zhongguo) occupying a central position in the 'realm under heaven' (tianxia) and surrounded by tributary states. In the $19^{\text {th }}$ century, this social imaginary was displaced by new narratives that relocated China from

\footnotetext{
${ }^{121}$ Nygård and Strang 2017, 63.

${ }^{122}$ Nygård and Strang 2017, 58. See also Nygård and Strang 2016, Stenius 2017.

${ }^{123}$ Liu 1999, 36-37.

${ }^{124}$ Nygård and Strang 2017, 56.

${ }^{125}$ Asad 1986, 158.

${ }^{126}$ Asad 1986, 157-58.

${ }^{127}$ Asad 1986, 158.
} 
the realm under heaven to a world populated by dozens of independent states. ${ }^{128}$ In terms of international practice, there was a displacement of ritualistic procedural norms by international law and diplomacy. ${ }^{129}$ In addition to this spatial restructuring, which transformed China from the exceptional Middle Kingdom to one state among many, there was also a temporal shift: the traditional temporal rhythm based on cycles of dynastic change was displaced by Hegelian philosophy of history and Social Darwinian theory of natural history, both of which were characterized by linear temporalities. ${ }^{130}$

Paralleling these social and political transformations, the Chinese language underwent massive changes as old words acquired new meanings and hundreds of new words - some sources count as many as 1266 neologisms - were coined to make sense of foreign texts and concepts pouring into the country, often via Japan. ${ }^{131}$ The lack of a similar restructuring of Western languages testifies to the unequal relations of conceptual exchange in this period: for the most part it was non-Western languages that were moulded to establish a better fit with the Western social imaginary, rather than the reverse. In addition to the invention of new words as equivalents of Western concepts, the meaning of many existing Chinese words was deferred to a foreign counterpart. Liu refers to this as the production of a 'super-sign' or 'a hetero-cultural signifying chain that crisscrosses the semantic fields of two or more languages simultaneously'. ${ }^{132}$ Super-signs transcend linguistic boundaries 'by acting out the verbal unit of one language and simultaneously displacing its signification onto a foreign language or languages'. ${ }^{133}$ Put differently, super-signs signal the 'entanglement' of two or more signs from different languages as these languages interact. ${ }^{134} \mathrm{~A}$ prominent example is the coupling of the Chinese character $y i$ to the English word barbarian through the Treaty of Tianjin in 1858, producing the Chinese-English super-sign yi/barbarian. Instead of being related meaningfully to other Chinese terms such as xiren (westerner) or to the official Manchu equivalent tulergi (outer), the meaning of $y i$ henceforth derived from the English language - simply put, yi became the equivalent of barbarian. In addition, the Treaty of Tianjin established an official ban on the use of the Chinese character $y i$, meaning that a violation of the integrity of the super-sign yi/barbarian could be seen as a violation of international law. Crucially, it was only the Chinese character, not the English word, which was prohibited from international circulation. The English word barbarian thus came to enjoy a doubly privileged status in this semantic couple: not only was it the authoritative signified of the super-sign yi/barbarian, the English word also went uncensored in international law. ${ }^{135}$

The production of the Chinese-English super-sign yi/barbarian is a relatively clear-cut case of the Chinese language being subordinated to English hegemony

\footnotetext{
${ }^{128}$ Chow 2001, 48-50.

${ }^{129}$ Svarverud 2007, Suzuki 2009, 140-76.

${ }^{130}$ Chow 2001, 50-53.

${ }^{131}$ Gunn 1991, Liu 1995, Lackner et al. 2001.

${ }^{132}$ Liu 2004, 13.

${ }^{133}$ Liu 2004, 14.

${ }^{134}$ On conceptual entanglement, see especially Pernau 2012, Wigen 2015, 435-39.

${ }^{135}$ Liu 2004, 31-69.
} 
through one of the many 'unequal treaties' imposed on the Qing Empire. In other contexts, however, Chinese officials were able to exercise more significant agency on the outcome of linguistic politics. With regards to the diplomatic negotiations over Tibet's international status in 1904-1906, for example, Amanda Cheney has demonstrated how Chinese officials purposefully appropriated Western legal concepts in order to resist British attempts to define China's authority over Tibet as 'suzerainty' rather than 'sovereignty'. In testimony to the skill and determination of Chinese officials, the final agreement made no mention of suzerainty: Tibet's international status remained ambiguous, facilitating its later incorporation into China. Even if Tibet was indeed translated and relocated from the Sinocentric world order to the modern international order, the diplomatic negotiations should be seen as 'a remarkable success for Chinese diplomacy.' ${ }^{136}$ More generally, the Tibetan case demonstrates how peripheral actors could, against the odds, mould the emerging international order in their favour by 'playing a weak hand well'. ${ }^{137}$ The modern international order may be profoundly Eurocentric, yet it is not European. ${ }^{138}$

\section{Institutionalization}

A key difference in the international/interlingual relations of Western and non-Western states today concerns the relative discrepancy between the domestic and the international languages. Combining Robert Putnam's notion of 'two-level games' with Ludwig Wittgenstein's notion of 'language games', Wigen proposes the notion of 'two-level language games' as a way of understanding this gap. ${ }^{139}$ The concentration of symbolic and material power in the hands of the modern state means that the state is able to approach a monopoly on the domestic language game. However, the entry of the state into international society requires the state to also participate in the language game of that society. ${ }^{140}$ Given the hegemonic position of Western states in the formation of the modern international order, the discrepancy between the domestic and the international language games is negligible for them. In contrast, non-Western states face a much wider discrepancy between the two games: these states joined an international society 'the rules of which they did not create. ${ }^{141}$ With regards to the maintenance of political legitimacy, this places non-Western states in a difficult situation: 'if the domestic language game is significantly different from those of international society, statesmen not only can, but will have to, engage in multi-vocal signalling in order to legitimize the same decision or practice. ${ }^{142}$ The more a state tries to resist Westernization,

\footnotetext{
${ }^{136}$ Cheney 2017, 781.

${ }^{137}$ Cheney 2017, 782.

${ }^{138}$ Another noteworthy sphere of contestation and agency concerns the existence of competing translations for key concepts or texts, as different translations could underpin different political programmes. In the case of China, this can be seen in Liang Qichao and Sun Yat-sen's contrasting conceptualizations of 'society' and 'economy', for example (Tian 2014).

${ }^{139}$ Wigen 2015, 429.

${ }^{140}$ Wigen 2015, 432.

${ }^{141}$ Zarakol 2011, 6. See also Zarakol 2014.

${ }^{142}$ Wigen 2015, 432.
} 
the greater the gulf between the domestic and the international language games becomes. This, in a nutshell, is the quandary of the post-colonial state: 'to fashion a "modern" national culture that is nevertheless not Western'. ${ }^{143}$

The most obvious manifestation of international linguistic hierarchy is the hegemony of English as the global language. ${ }^{144}$ The International Monetary Fund and the World Bank both have English as their official language, while the World Trade Organization works in English, French, and Spanish. Although some international organizations such as the United Nations recognize a broader range of working languages, the overarching theme is the nigh universal recurrence of English. However, the crucial point is not the dominance of English per se - after all, there are a multiplicity of Englishes spoken around the world, some of them mutually incomprehensible. ${ }^{145}$ Far more subtle than the hegemony of English is the hegemony of the Eurocentric concepts that define the modern social imaginary and set the standard against which all experiences of modernity are measured. The hegemony of these concepts is, of course, intrinsically intertwined with the hegemony of the Western languages, especially English, insofar as it is these languages that have historically served as the principal material bearers of the concepts. And yet, as this paper has been at pains to emphasize, concepts are not reducible to words. In the same way that money as measure of value transcends all particular currencies that serve as its symbols, the measure of value in the linguistic sphere transcends all particular languages: English as the global lingua franca is not the measure of value, but merely the most prominent medium of exchange through which concepts circulate. The measure of value is, instead, a specific constellation of Eurocentric concepts - a constellation known as the modern international order.

The institutionalization of the Western experience of modernity in the form of the modern international order is in many ways the logical corollary of the universalization of Eurocentric concepts - to this extent, the modern international order functions as a proxy for the West. However, this moment of institutionalization also entails a crucial dialectical reversal. During the first phase of conceptual universalization, the West was openly hailed as the gold standard of modernity and served as the privileged source text for 'translated' modernities. By way of contrast, the subsequent institutionalization of the Western experience in the form of the modern international order effaces the West as the principal source of this order. In John Hobson's terms, the 'manifest Eurocentrism' of the colonial era is replaced with a 'subliminal Eurocentrism' whose 'Eurocentric properties are hidden from immediate view'. ${ }^{146}$ Elevated to the status of universal equivalent, the Western experience effectively begins to function as the translated text relative to which all experiences including that of the West itself - are cast as source texts: at the very moment that the Western experience is institutionalized as universal equivalent, this experience also becomes particularized as one experience among many. That is to say, the Western experience functions both as the universal genus (the form of the modern international order) and one particular species (the Western experience of

\footnotetext{
${ }^{143}$ Chatterjee 1993, 6.

${ }^{144}$ Phillipson 1992, Crystal 2003.

${ }^{145}$ McArthur 1998.

${ }^{146}$ Hobson 2012, 10.
} 
modernity) within that genus: 'next to "normal" species, one always comes across a supplementary species which holds the place of the genus itself. ${ }^{147}$ Among a multiplicity of modernities, therefore, the Western variant not only holds a historically privileged position, but is also the very form within which this multiplicity can manifest itself.

This dialectical reversal is reflected in what Hill describes as a shift in emphasis from 'generalizing' to 'relativizing' universalism. Whereas generalizing universalism is about concepts being 'used as if they were valid in any situation', relativizing universalism describes those instances where 'the concept was used as if it were universally valid as a category but described a phenomenon that was essentially different in every iteration'. ${ }^{48}$ Significantly, Hill locates the shift towards the relativizing use of concepts in the mid- $20^{\text {th }}$ century, which correlates with decolonization. ${ }^{149}$ The formal end of imperialism therefore does not simply mark the end of international hierarchy. To the contrary, it also serves to entrench this hierarchy by effacing the historical origins of the political concepts that underpin the modern international order. It is precisely at this juncture that we find the historical origins of relativizing ideologies such as 'multiculturalism" ${ }^{\text {'50 }}$ and 'multiple modernities'151 that hold so much sway today. The ongoing scramble to promote national and regional approaches among IR scholars is part of the same trend. ${ }^{152}$ These relativizing discourses offer the illusion of plurality and equality while leaving the underlying conceptual categories - culture, modernity, nation, region, and so on undisturbed. Despite appearances, such plurality is not inherently opposed to the homogenizing tendencies of the universal equivalent. To the contrary, it is the homogenizing impact of the universal equivalent that underpins the global circulation of differences.

To sum up, birth of the modern international order can be understood in terms of two phases that correspond to Marx's delineation of the general form and the money form. The first phase, conceptual universalization, captures the innumerable series of unequal exchanges through which Western political concepts were translated into other languages across the globe: the Western experience of modernity served as the privileged source text from which other 'translated' experiences of modernity were derived. The second phase, institutionalization, refers to the emergence of global translatability and the sedimentation of the Western experience of modernity in the conceptual architecture of the modern international order. This passage entails a dialectical reversal, as the Western experience of modernity ceases to serve as the privileged source text and instead begins to function as the universal translation - the universal equivalent - that undergirds the global practice of international/interlingual relations. In this way, the Western experience of modernity continues to silently inform the international standards that govern state behaviour, even as the superiority of the West is downplayed or denied.

\footnotetext{
${ }^{147}$ Žižek 2008, 44.

${ }^{148}$ Hill 2013, 150.

${ }^{149}$ Hill 2013, 151.

${ }^{150}$ For a critique, see Žižek 1997.

${ }^{151}$ For a critique, see Bhambra 2007.

${ }^{152}$ See, for example, Tickner and Wæver 2009, Acharya and Buzan 2010.
} 


\section{Conclusion: in other wor $(\mathrm{l}) \mathrm{ds}$}

By demonstrating how social order is found(ed) in translation, this paper has challenged IR's prevailing tendency to operate with a 'supra-social and non-historical conception of the international'. ${ }^{153}$ The notion of translation cuts right through the transhistorical pretensions of IR and recasts the modern international order as a social imaginary that has crystallized historically out of concrete encounters, exchanges, and entanglements. Specifically, I have suggested that important insights can be gained by reading the origins of the modern international order through Marx's analysis of the universal equivalent. In this reading, the modern international order emerges as the concrete solution to the asymmetries and contradictions that structured the colonial system of conceptual (ex)change. As universal equivalent, the modern international order functions as the socially recognized metalanguage that undergirds the miracle of global translatability and makes international/interlingual relations possible on a global scale.

The consolidation of the universal equivalent marks the passage from the general form to the money form, whereby commodities become differentiated into commodities and money. In an analogous manner, the institutionalization of the modern international order as universal equivalent brings about the incipient separation of this order from the particular historical experience that birthed it: upon its formation, the modern international order detaches itself from its colonial roots and acquires an increasingly autonomous existence from the West. This dialectical passage from the general form to the money form - from the hierarchical imperial order to the 'flat' or 'anarchical' international order - has contradictory implications for the future of international/interlingual hierarchy and world order.

On the one hand, the modern international order is the final and most insidious form of colonialism. As the culmination of a highly unequal series of exchanges, the conceptual architecture of the modern international order is the living embodiment of undead colonial hierarchies. The process of conceptual universalization in the long $19^{\text {th }}$ century entailed not only the universalization of the Western experience of modernity but also, in tandem, the universalization of modernity's 'constitutive and darker side, coloniality'. ${ }^{154}$ This neocolonial arrangement is underpinned by a new and more pernicious form of Eurocentrism that obscures its own Eurocentric properties and thereby renders itself resistant to critique: explicit discourse of imperial rule is displaced by dispassionate notions of hegemony and dependency, while the standard of civilization is rearticulated in the seemingly neutral guise of development indexes and human rights norms. ${ }^{155}$ It is no longer the West, but the ethereal 'international', that functions as the measure of value and the ground of comparison. As a result, the Eurocentrism of international/interlingual relations is no longer reducible to the hegemony of the English language, not even to the hegemony of the former colonial languages more generally. Instead, the Eurocentrism of international/interlingual relations today encompasses the historical trajectories of all those modern political languages, whether Western or non-Western, that reinforce and reproduce the ideological project of the nation-state.

\footnotetext{
${ }^{153}$ Matin 2011, 356.

${ }^{154}$ Mignolo 2011, 2.

${ }^{155}$ See, for example, Donnelly 1998, Rist 2008, Hobson 2012.
} 
To reduce the question of Eurocentrism to the question of Western (linguistic) hegemony is to overlook the inescapably global constitution of the modern international order. As Dipesh Chakrabarty observes, the universalization of the nationstate model is something that 'European imperialism and third-world nationalisms have achieved together. ${ }^{156}$ In the postcolonial/neocolonial era, the basic concepts of the modern international order have become sedimented in a multiplicity of political languages around the world, each imbuing these concepts with a unique yet strikingly familiar hue.

On the other hand, for all its insidiousness, the iron cage of coloniality does not constitute a self-enclosed totality. Fundamentally, this is because the modern international order is not a transcendental given but a social convention that has crystallized out of concrete historical processes. Even if the conceptual architecture of the modern international order gives pride of place to the Western experience of modernity, its formal separation from the Western experience also creates an opening for criticism and transformation. The miracle of global translatability may have been forged through the material and symbolic violences of Western imperialism, yet the maintenance of this miracle no longer depends on Western hegemony - all it requires is the continuation of exchange and entanglement. In this way, perhaps somewhat counterintuitively, the universalization of coloniality actually multiplies the potentialities for its overcoming: through the universalization of coloniality, each and every language, each and every region, becomes a potential source of anticolonial critique. What matters is neither the language in which, nor the region from which, this critique is articulated, but only the willingness to engage disruptively with the Eurocentric basic concepts that structure the modern international order. In the eloquent words of Aamir Mufti: 'There are entire worlds to be discovered "beyond English", not in some geographically distinct and distant place but right next to you, wherever you may happen to be, and even in your own (English) speech itself. ${ }^{157}$

Understood as a concrete social imaginary, the modern international order cannot be decolonized. Rather, the continuation of critical exchange may bring about a transformation of this order such that it ceases to be recognizable as the modern international order (arguably, the growing currency of notions such as 'world politics' and 'global governance' suggests that such a transformation is already underway). What, exactly, this new social imaginary will look like remains an open question. The only certainty is that it will entail its own share of exclusions and marginalizations - something is always lost in translation. This foundational violence can never be fully eliminated, but its baneful effects can, hopefully, be tempered through careful reflection and tireless critique.

Acknowledgements. Earlier versions of this article were presented at a $\mathrm{PhD}$ workshop at the University of Cambridge in March 2019, at the Millennium annual conference in October 2019, and at an interlingual relations workshop at King's College London in January 2020. I am grateful to the participants at these events for their helpful questions and comments. Special thanks to Ayşe Zarakol, Lucas de Oliveira Paes, Paul Beaumont, Zeynep Gülşah Çapan, Einar Wigen, and Oumar Ba for their valuable feedback

\footnotetext{
${ }^{156}$ Chakrabarty 2000, 41

${ }^{157}$ Mufti 2016, 199.
} 
on earlier drafts, as well as the editors of International Theory and two anonymous reviewers for their generous guidance on how to improve the article. Any remaining shortcomings are my own.

\section{References}

Abu-Lughod, Janet L. 1989. Before European Hegemony: The World System A.D. 1250-1350. Oxford: Oxford University Press.

Acharya, Amitav, and Barry Buzan, eds. 2010. Non-Western International Relations Theory: Perspectives from Asia. London: Routledge.

Anderson, Benedict. 2006. Imagined Communities: Reflections on the Origin and Spread of Nationalism, Revised ed. London: Verso.

Anghie, Antony. 2005. Imperialism, Sovereignty and the Making of International Law. Cambridge: Cambridge University Press.

Asad, Talal. 1986. "The Concept of Cultural Translation in British Social Anthropology." In Writing Culture: The Poetics and Politics of Ethnography, edited by James Clifford, and George E. Marcus, 141-64. Berkeley: University of California Press.

Bayly, Christopher A. 2004. The Birth of the Modern World, 1780-1914: Global Connections and Comparisons. Oxford: Blackwell.

Benveniste, Émile. 1971. Problems in General Linguistics. Translated by Mary Elizabeth Meek. Coral Gables: University of Miami Press.

Berenskoetter, Felix. 2017. “Approaches to Concept Analysis." Millennium: Journal of International Studies 45 (2): 151-73.

Bhambra, Gurminder K. 2007. Rethinking Modernity: Postcolonialism and the Sociological Imaginary. Basingstoke: Palgrave Macmillan.

Bially Mattern, Janice, and Ayşe Zarakol. 2016. "Hierarchies in World Politics." International Organization 70 (3): 623-54.

Bourdieu, Pierre. 1991. Language and Symbolic Power. Translated by Gino Raymond and Matthew Adamson. Cambridge, MA: Harvard University Press.

Branch, Jordan. 2012. “'Colonial Reflection' and Territoriality: The Peripheral Origins of Sovereign Statehood." European Journal of International Relations 18 (2): 277-97.

Buzan, Barry, and George Lawson. 2015. The Global Transformation: History, Modernity and the Making of International Relations. Cambridge: Cambridge University Press.

Chakrabarty, Dipesh. 2000. Provincializing Europe: Postcolonial Thought and Historical Difference. Princeton: Princeton University Press.

Chatterjee, Partha. 1993. The Nation and Its Fragments: Colonial and Postcolonial Histories. Princeton: Princeton University Press.

Cheney, Amanda J. 2017. "Tibet Lost in Translation: Sovereignty, Suzerainty and International Order Transformation, 1904-1906." Journal of Contemporary China 26 (107): 769-83.

Chow, Kai-wing. 2001. "Narrating Nation, Race, and National Culture: Imagining the Hanzu Identity in Modern China." In Constructing Nationhood in Modern East Asia, edited by Kai-wing Chow, Kevin M. Doak, and Poshek Fu, 47-83. Ann Arbor: University of Michigan Press.

Crystal, David. 2003. English as a Global Language, 2nd ed. Cambridge: Cambridge University Press.

de Brunhoff, Suzanne. 1976. Marx on Money. Translated by Maurice J. Goldbloom. New York: Urizen Books. Deleuze, Gilles, and Félix Guattari. 1994. What is Philosophy? New York: Columbia University Press.

Der Derian, James, and Michael J. Shapiro, eds. 1989. International/Intertextual Relations: Postmodern Readings of World Politics. New York: Lexington Books.

Derrida, Jacques. 1981. Positions. Translated by Alan Bass. London: Athlone Press.

Derrida, Jacques. 1985. The Ear of the Other: Otobiography, Transference, Translation. Edited by Christie McDonald. Translated by Peggy Kamuf. New York: Schocken Books.

Derrida, Jacques. 1988. Limited Inc. Evanston: Northwestern University Press.

Derrida, Jacques. 1998. Monolingualism of the Other: or, The Prosthesis of Origin. Translated by Patrick Mensah. Stanford: Stanford University Press.

de Saussure, Ferdinand. 1959. Course in General Linguistics. Translated by Wade Baskin. New York: Philosophical Library. 
De Swaan, Abram. 2001. Words of the World: The Global Language System. Cambridge: Polity. Donnelly, Jack. 1998. “Human Rights: A New Standard of Civilization?” International Affairs 74 (1): 1-23. Foucault, Michel. 1984. "Truth and Power." In The Foucault Reader, edited by Paul Rabinow, 51-75. New York: Pantheon Books.

Freeden, Michael. 1996. Ideologies and Political Theory: A Conceptual Approach. Oxford: Clarendon.

Gadamer, Hans-Georg. 2004. Truth and Method. Translated by Donald G. Marshall and Joel Weinsheimer, 2nd ed. London and New York: Continuum.

Goux, Jean-Joseph. 1990. Symbolic Economies: After Marx and Freud. Translated by Jennifer Curtiss Gage. Ithaca: Cornell University Press.

Graeber, David. 2011. Debt: The First 5,000 Years. Brooklyn: Melville house.

Gunn, Edward. 1991. Rewriting Chinese: Style and Innovation in Twentieth-Century Chinese Prose. Stanford: Stanford University Press.

Guzzini, Stefano. 2013. “The Ends of International Relations Theory: Stages of Reflexivity and Modes of Theorizing." European Journal of International Relations 19 (3): 521-41.

Hansen, Lene. 2006. Security as Practice: Discourse Analysis and the Bosnian War. London and New York: Routledge.

Heilbron, Johan. 1999. "Towards a Sociology of Translation: Book Translations as a Cultural World-System.” European Journal of Social Theory 2 (4): 429-44.

Hill, Christopher L. 2013. "Conceptual Universalization in the Transnational Nineteenth Century." In Global Intellectual History, edited by Samuel Moyn and Andrew Sartori, 134-58. New York: Columbia University Press.

Hobson, John M. 2004. The Eastern Origins of Western Civilisation. Cambridge: Cambridge University Press. Hobson, John M. 2012. The Eurocentric Conception of World Politics: Western International Theory, 17602010. Cambridge: Cambridge University Press.

Hobson, John M. 2014. “The Twin Self-Delusions of IR: Why 'Hierarchy' and Not 'Anarchy' is the Core Concept of IR.” Millennium: Journal of International Studies 42 (3): 557-75.

Hopkins, Antony G., ed. 2002. Globalization in World History. London: Pimlico.

Hutchings, Kimberly. 2011. "Dialogue Between Whom? The Role of the West/Non-West Distinction in Promoting Global Dialogue in IR.” Millennium: Journal of International Studies 39 (3): 639-47.

Hyvärinen, Matti, Jussi Kurunmäki, Kari Palonen, Tuija Pulkkinen, and Henrik Stenius, eds. 2003. Käsitteet Liikkeessä: Suomen Poliittisen Kulttuurin Käsitehistoria. Tampere: Vastapaino.

Jahn, Beate. 2000. The Cultural Construction of International Relations: The Invention of the State of Nature. Basingstoke: Palgrave.

Jakobson, Roman. 2000. “On Linguistic Aspects of Translation.” In The Translation Studies Reader, edited by Lawrence Venuti, 113-18. London and New York: Routledge.

Jordheim, Helge, and Iver B. Neumann. 2011. "Empire, Imperialism and Conceptual History.” Journal of International Relations and Development 14 (2): 153-85.

Jordheim, Helge, and Einar Wigen. 2018. "Conceptual Synchronisation: From Progress to Crisis." Millennium: Journal of International Studies 46 (3): 421-39.

Kayaoğlu, Turan. 2010. "Westphalian Eurocentrism in International Relations Theory." International Studies Review 12 (2): 193-217.

Koselleck, Reinhart. 1996. "A Response to Comments on the Geschichtliche Grundbegriffe." In The Meaning of Historical Terms and Concepts: New Studies on Begriffsgeschichte, edited by Hartmut Lehmann and Melvin Richter, Translated by Melvin Richter and Sally E. Robertson, 59-70. Washington, DC: German Historical Institute.

Koselleck, Reinhart. 2002. The Practice of Conceptual History: Timing History, Spacing Concepts. Translated by Todd Samuel Presner. Stanford: Stanford University Press.

Koselleck, Reinhart. 2004. Futures Past: On the Semantics of Historical Time. Translated by Keith Tribe. New York: Columbia University Press.

Koselleck, Reinhart. 2006. "Conceptual History, Memory, and Identity: An Interview with Reinhart Koselleck.” Contributions to the History of Concepts 2 (1): 99-127.

Koselleck, Reinhart. 2011. "Introduction and Prefaces to the Geschichtliche Grundbegriffe." Translated by Michaela Richter. Contributions to the History of Concepts 6 (1): 1-5, 7-25, 27-37.

Krebs, Ronald R., and Patrick Thaddeus Jackson. 2007. "Twisting Tongues and Twisting Arms: The Power of Political Rhetoric.” European Journal of International Relations 13 (1): 35-66. 
Lackner, Michael, Iwo Amelung, and Joachim Kurtz, eds. 2001. New Terms for New Ideas: Western Knowledge and Lexical Change in Late Imperial China. Leiden: Brill.

Lake, David A. 2009. Hierarchy in International Relations. Ithaca: Cornell University Press.

Lapavitsas, Costas. 1991. "The Theory of Credit Money: A Structural Analysis." Science \& Society 55 (3): 291-322.

Lapavitsas, Costas. 2005. "The Universal Equivalent as Monopolist of the Ability to Buy." In Marx's Theory of Money: Modern Appraisals, edited by Fred Moseley, 95-110. Basingstoke: Palgrave Macmillan.

Lefevere, André. 1999. "Composing the Other." In Post-Colonial Translation: Theory and Practice, edited by Susan Bassnett and Harish Trivedi, 75-94. London and New York: Routledge.

Lefevere, André, and Susan Bassnett. 1998. "Introduction: Where are We in Translation Studies?" In Constructing Cultures: Essays on Literary Translation, 1-11. Clevedon: Multilingual Matters.

Leira, Halvard. 2019. “The Emergence of Foreign Policy.” International Studies Quarterly 63 (1): 187-98.

Liu, Lydia H. 1995. Translingual Practice: Literature, National Culture, and Translated Modernity - China, 1900-1937. Stanford: Stanford University Press.

Liu, Lydia H. 1999. "The Question of Meaning-Value in the Political Economy of the Sign." In Tokens of Exchange: The Problem of Translation in Global Circulations, edited by Lydia H. Liu, 13-41. Durham: Duke University Press.

Liu, Lydia H. 2004. The Clash of Empires: The Invention of China in Modern World Making. Cambridge, MA: Harvard University Press.

Marjanen, Jani. 2009. "Undermining Methodological Nationalism: Histoire Croisée of Concepts as Transnational History." In Transnational Political Spaces: Agents-Structures-Encounters, edited by Mathias Albert, Gesa Bluhm, Jan Helmig, Andreas Leutzsch, and Jochem Walter, 239-63. Frankfurt am Main: Campus Verlag.

Marjanen, Jani. 2017. “Transnational Conceptual History, Methodological Nationalism and Europe." In Conceptual History in the European Space, edited by Willibald Steinmetz, Michael Freeden, and Javier Fernández-Sebastian, 139-74. New York and Oxford: Berghahn.

Marx, Karl. 1973. Grundrisse: Foundations of the Critique of Political Economy. Translated by Martin Nicolaus. London: Penguin.

Marx, Karl. 1976. Capital: A Critique of Political Economy: Volume One. Translated by Ben Fowkes. London: Penguin.

Matin, Kamran. 2011. "Redeeming the Universal: Postcolonialism and the Inner Life of Eurocentrism." European Journal of International Relations 19 (2): 353-77.

McArthur, Tom. 1998. The English Languages. Cambridge: Cambridge University Press.

Mignolo, Walter D. 2011. The Darker Side of Western Modernity: Global Futures, Decolonial Options. Durham: Duke University Press.

Mufti, Aamir R. 2016. Forget English! Orientalisms and World Literature. Cambridge, MA: Harvard University Press.

Nygård, Stefan, and Johan Strang. 2016. "Facing Asymmetry: Nordic Intellectuals and Center-Periphery Dynamics in European Cultural Space." Journal of the History of Ideas 77 (1): 75-97.

Nygård, Stefan, and Johan Strang. 2017. "Conceptual Universalization and the Role of the Peripheries." Contributions to the History of Concepts 12 (1): 55-75.

Osterhammel, Jürgen. 2014. The Transformation of the World: A Global History of the Nineteenth Century. Princeton: Princeton University Press.

Ostler, Nicholas. 2010. The Last Lingua Franca: English Until the Return of Babel. London: Allen Lane.

Palonen, Kari. 1999. "Rhetorical and Temporal Perspectives on Conceptual Change: Theses on Quentin Skinner and Reinhart Koselleck." Finnish Yearbook of Political Thought 3: 41-59.

Palonen, Kari. 2003a. "Eurooppalaiset poliittiset käsitteet suomalaisissa pelitiloissa." In Käsitteet Liikkeessä: Suomen Poliittisen Kultuurin Käsitehistoria, edited by Matti Hyvärinen, Jussi Kurunmäki, Kari Palonen, Tuija Pulkkinen, and Henrik Stenius, 569-87. Tampere: Vastapaino.

Palonen, Kari. 2003b. "Translation, Politics and Conceptual Change." Finnish Yearbook of Political Thought 7: 15-35.

Palonen, Kari. 2012. "Reinhart Koselleck on Translation, Anachronism and Conceptual Change." In Why Concepts Matter: Translating Social and Political Thought, edited by Martin J. Burke and Melvin Richter, 73-92. Leiden: Brill. 
Pernau, Margrit. 2012. "Whither Conceptual History? From National to Entangled Histories." Contributions to the History of Concepts 7 (1): 1-11.

Pernau, Margrit. 2016. "Provincializing Concepts: The Language of Transnational History." Comparative Studies of South Asia, Africa and the Middle East 36 (3): 483-99.

Phillipson, Robert. 1992. Linguistic Imperialism. Oxford: Oxford University Press.

Pocock, John G. A. 1996. "Concepts and Discourses: A Difference in Culture? Comment on a Paper by Melvin Richter." In The Meaning of Historical Terms and Concepts: New Studies on Begriffsgeschichte, edited by Hartmut Lehmann and Melvin Richter, 47-58. Washington, DC: German Historical Institute.

Pym, Anthony. 2004. "The Use of Translation in International Organizations." In Translation: An International Encyclopedia of Translation Studies, edited by Harald Kittel, Hugo Steger, Gerold Ungeheuer, and Herbert Ernst Wiegand, Vol. I, 85-92. Berlin and New York: Walter de Gruyter.

Pym, Anthony. 2010. Translation and Text Transfer: An Essay on the Principles of Intercultural Communication, Revised ed. Tarragona: Intercultural Studies Group.

Rist, Gilbert. 2008. The History of Development: From Western Origins to Global Faith. Translated by Patrick Camiller, 3rd ed. London and New York: Zed Books.

Roshchin, Evgeny. 2017. Friendship Among Nations: History of a Concept. Manchester: Manchester University Press.

Schaffer, Frederic C. 1998. Democracy in Translation: Understanding Politics in an Unfamiliar Culture. Ithaca: Cornell University Press.

Seth, Sanjay. 2011. "Postcolonial Theory and the Critique of International Relations." Millennium: Journal of International Studies 40 (1): 167-83.

Shell, Marc. 1982. Money, Language, and Thought: Literary and Philosophic Economies from the Medieval to the Modern Era. Baltimore and London: The Johns Hopkins University Press.

Skinner, Quentin. 1969. "Meaning and Understanding in the History of Ideas." History and Theory 8 (1): 3-53.

Skinner, Quentin. 1988. “A Reply to My Critics.” In Meaning and Context: Quentin Skinner and his Critics, edited by James Tully, 231-88. Cambridge: Polity.

Skinner, Quentin. 1999. "Rhetoric and Conceptual Change." Finnish Yearbook of Political Thought 3: 60-73. Skinner, Quentin. 2002. "Retrospect: Studying Rhetoric and Conceptual Change." In Visions of Politics: Volume One: Regarding Method, 175-87. Cambridge: Cambridge University Press.

Steiner, George. 1975. After Babel: Aspects of Language and Translation. Oxford: Oxford University Press. Stenius, Henrik. 2004. "The Finnish Citizen: How a Translation Emasculated the Concept." Redescriptions: Yearbook of Political Thought and Conceptual History 8: 172-88.

Stenius, Henrik. 2017. "Concepts in a Nordic Periphery." In Conceptual History in the European Space, edited by Willibald Steinmetz, Michael Freeden, and Javier Fernández-Sebastian, 263-80. New York and Oxford: Berghahn.

Strauss, Claudia. 2006. “The Imaginary.” Anthropological Theory 6 (3): 322-44.

Stritzel, Holger. 2014. Security in Translation: Securitization Theory and the Localization of Threat. Basingstoke: Palgrave Macmillan.

Suzuki, Shago. 2009. Civilization and Empire: China and Japan's Encounter with European International Society. London and New York: Routledge.

Svarverud, Rune. 2007. International Law as World Order in Late Imperial China: Translation, Reception and Discourse, 1847-1911. Leiden: Brill.

Taylor, Charles. 2002. "Modern Social Imaginaries." Public Culture 14 (1): 91-124.

Tian, Hailong. 2014. "Differing Translations, Contested Meanings: A Motor for the 1911 Revolution in China?" In A Global Conceptual History of Asia, 1860-1940, edited by Hagen Schulz-Forberg, 43-60. London: Pickering \& Chatto.

Tickner, Arlene B., and Ole Wæver, eds. 2009. International Relations Scholarship around the World. London and New York: Routledge.

Venuti, Lawrence. 1996. "Translation as Social Practice: or, The Violence of Translation." In Translation Horizons Beyond the Boundaries of Translation Spectrum: A Collection of Essays Situation and Proposing New Directions and Major Issues in Translation Studies, edited by Marilyn Gaddis Rose, 195-213. Binghampton: Center for Research in Translation, State University of New York.

Virno, Paolo. 2009. "The Money of Language: Hypotheses on the Role of Negation in Saussure." Translated by Timothy Campbell. Diacritics 39 (4): 149-61. 
Wigen, Einar. 2015. "Two-Level Language Games: International Relations as Inter-Lingual Relations." European Journal of International Relations 21 (2): 427-50.

Wigen, Einar. 2018. State of Translation: Turkey in Interlingual Relations. Ann Arbor: University of Michigan Press.

Williams, Michael. 2000. "Why Marx Neither Has Nor Needs a Commodity Theory of Money." Review of Political Economy 12 (4): 435-51.

Zarakol, Ayşe. 2011. After Defeat: How the East Learned to Live with the West. Cambridge: Cambridge University Press.

Zarakol, Ayşe. 2014. "What Made the Modern World Hang Together: Socialisation or Stigmatisation?" International Theory 6 (2): 311-32.

Zarakol, Ayşe, ed. 2017a. Hierarchies in World Politics. Cambridge: Cambridge University Press.

Zarakol, Ayşe. 2017b. "Theorising Hierarchies: An Introduction." In Hierarchies in World Politics, edited by Ayşe Zarakol, 1-14. Cambridge: Cambridge University Press.

Žižek, Slavoj. 1997. "Multiculturalism, Or, the Cultural Logic of Multinational Capitalism." New Left Review 225: 28-51.

Žižek, Slavoj. 2008. For They Know Not What They Do: Enjoyment as a Political Factor, 2nd ed. London and New York: Verso.

Cite this article: Heiskanen, J. 2021. "Found in translation: the global constitution of the modern international order." International Theory 13, 231-259, doi:10.1017/S1752971920000317 